\title{
Corrigendum: CD90+ stromal cells are non-professional innate immune effectors of the human colonic mucosa
}

\author{
Benjamin M. J. Owens ${ }^{1}$, Tessa A. M. Steevels ${ }^{1}$, Michael Dudek ${ }^{1}$, David Walcott ${ }^{1}$, \\ Mei-Yi Sun ${ }^{2}$, Alice Mayer ${ }^{2}$, Philip Allan ${ }^{1}$ and Alison Simmons ${ }^{1,2 *}$ \\ ${ }^{1}$ Translational Gastroenterology Unit, Nuffield Department of Medicine, Experimental Medicine Division, John Radcliffe Hospital, \\ University of Oxford, Oxford, UK, ${ }^{2}$ MRC Human Immunology Unit, John Radcliffe Hospital, Weatherall Institute of Molecular \\ Medicine, University of Oxford, Oxford, UK
}

Keywords: stromal cells, mucosal immunology, innate immunity, intestinal homeostasis, colon

\section{A corrigendum on}

$\mathrm{CD90}^{+}$stromal cells are non-professional innate immune effectors of the human colonic mucosa by Owens BMJ, Steevels TAM, Dudek M, Walcott D, Sun M-Y, Mayer A, et al. Front Immunol (2013) 4:307. doi: 10.3389/fimmu.2013.00307

\section{Current Acknowledgments}

The authors thank Professor David Holden, Imperial College London, for the kind gift of GFPSalmonella enterica typhimurium. The authors thank Dr. Claire Pearson for critical review of the manuscript.

Edited and reviewed by: Rajaraman D. Eri, University of Tasmania, Australia

*Correspondence: Alison Simmons annabel.gordon@ndm.ox.ac.uk

Specialty section: This article was submitted to Mucosal Immunity, a section of the journal

Frontiers in Immunology

Received: 08 June 2015 Accepted: 08 June 2015

Published: 24 June 2015

Citation:

Owens BMJ, Steevels TAM Dudek $M$, Walcott $D$, Sun $M-Y$, Mayer A, Allan $P$ and Simmons $A$ (2015) Corrigendum: $C D 90^{+}$stromal cells are non-professional innate immune effectors of the human colonic mucosa.

Front. Immunol. 6:325. doi: 10.3389/fimmu.2015.00325

\section{New, Amended Acknowledgments}

The authors thank Professor David Holden, Imperial College London, for the kind gift of GFPSalmonella enterica typhimurium. The authors thank Dr. Claire Pearson for critical review of the manuscript and The Sir Jules Thorn Charitable Trust for their financial support.

Conflict of Interest Statement: The authors declare that the research was conducted in the absence of any commercial or financial relationships that could be construed as a potential conflict of interest.

Copyright (๑) 2015 Owens, Steevels, Dudek, Walcott, Sun, Mayer, Allan and Simmons. This is an open-access article distributed under the terms of the Creative Commons Attribution License (CC BY). The use, distribution or reproduction in other forums is permitted, provided the original author(s) or licensor are credited and that the original publication in this journal is cited, in accordance with accepted academic practice. No use, distribution or reproduction is permitted which does not comply with these terms. 